
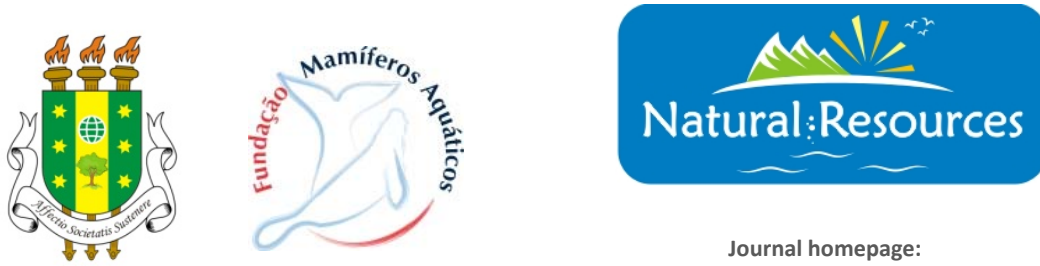

Journal homepage:

www.arvore.org.br/seer

\section{INSERÇÃO DA DISCIPLINA DE EDUCAÇÃO AMBIENTAL NO CURSO DE FORMAÇÃO DE SOLDADOS DO CORPO DE BOMBEIROS MILITAR DE PERNAMBUCO}

\section{RESUMO}

Este estudo de base Teórica tem por finalidade ampliar o campo de atuação dos Soldados formados pelo Corpo de Bombeiros Militar de Pernambuco, de modo a terem acesso a informações de cunho específico de educação ambiental, onde futuramente os formados nestes moldes, poderão atuar em escolas e em atendimento a esclarecimentos do público, quando os militares, estiverem em serviço ostensivo de guarda-vidas (militares que trabalham em praias). Não somente para prestar informações, mas fiscalizar e atuar de forma educativa, ao se deparar com situações que comprometam a ecologia marinha. Atualmente os alunos que participam da formação de soldado, são colocados à disposição do Curso de Formação de Soldados Bombeiro Militar (CFSd BM), que acontece no Campus De Ensino Metropolitano li. O curso tem uma carga horária média de 800 horas de aula (CFSd BM 2011), e são abordadas diversas matérias, as quais preparam o militar para a parte operacional do serviço de bombeiros, onde são fundamentais para a capacitação do soldado. Porém, dentre as disciplinas, não consta em sua malha curricular a formação/capacitação em nenhuma área ambiental. O projeto tem como objetivo inserir a disciplina de Educação Ambiental com uma carga horária de no mínimo 45 horas/aula, considerando a necessidade de preparo tanto teórico quanto didático da abordagem cotidiana por parte dos militares em escolas ou junto à população. Após a conclusão do curso com a inserção da disciplina, os militares capacitados deverão concorrer a suas escalas ordinárias, porém, deverão ministrar palestras em escolas próximas as unidades militares que servem. Para a contabilização da carga horária trabalhada, não seria alterada, somente a questão do serviço seria o de palestrar nas escolas. Esse projeto levaria a informação para a comunidade e no caso dos guarda-vidas, teriam o apoio do Projeto Orla (projeto do governo estadual, onde estrutura a orla marítima de forma integrada, para atender a população em vários aspectos, incluindo agora, fiscalização na área de ecologia marinha). Ao iniciar o projeto junto à comunidade, sabe-se que será algo em longo prazo, mas que seria necessário começar de alguma forma. E com o apoio do efetivo do Corpo de Bombeiros, pode ser uma participação relevante, pois teria um quantitativo de homens destinados também a ajudar o meio ambiente, e agora, devidamente instruídos para isso. No ultimo curso de formação de soldados, foram formados um quantitativo de 448 militares. Após a conclusão do curso, os militares foram encaminhados para diversas unidades dentro do Estado de Pernambuco. Se a cada curso de formação o efetivo for instruído com a disciplina de educação ambiental, estaremos formando um primeiro interventor junto a comunidade. Se cada militar conseguir implantar essa ideia em uma família, já terá sido valida a implantação da disciplina dentro da malha curricular. Estreitarmos os laços com a comunidade é especializar uma mão de obra na ajuda a manter a educação ambiental dentro das famílias, dentro da sociedade.

PALAVRAS-CHAVE: Educação Ambiental; Formação Militar; Corpo de Bombeiros.
Natural Resources, Aquidabã, v.3, n.2, Set 2013.

ISSN 2237-9290

\section{SECTION: Anais do Congresso}

Internacional de Ecotoxicologia

Marinha (ECOMAR 2013)

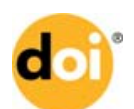

DOI: 10.6008/ESS2237-9290.2013.002.0018

Eduardo Lopes Corgosinho

Corpo de Bombeiros Militar de Pernambuco, Brasil http://lattes.cnpq.br/7551514173124909

eduardo.lopes85@hotmail.com

Received: 01/04/2013

Approved: 15/06/2013

Reviewed anonymously in the process of blind peer

\section{Referencing this:}

CORGOSINHO, E. L.. Inserção da disciplina de educação ambiental no curso de formação de soldados do Corpo De Bombeiros Militar de Pernambuco. Natural Resources, Aquidabã, v.3, n.2, p.23, 2013. DOI: http://dx.doi.org/10.6008/ESS2237$\underline{9290.2013 .002 .0018}$ 